\title{
AN INEXPENSIVE AND CONVENIENT PROCEDURE FOR CHLOROMETHYLATION OF AROMATIC HYDROCARBONS BY PHASE TRANSFER CATALYSIS IN AQUEOUS MEDIA
}

\author{
YU LIN HU, MING LU*, QIANG GE, PENG CHENG WANG, SHENG BIN ZHANG, TING TING LU
}

Chemical Engineering College, Nanjing University of Science and Technology, Nanjing 210094, PR China

(Received: July 14, 2009 - Accepted: December 17, 2009)

\begin{abstract}
Reaction of aromatic hydrocarbons catalyzed by a novel catalytic system consisting of zinc chloride, acetic acid, sulfuric acid and PEG-800 in aqueous media under PTC conditions results in chloromethylation in good to excellent yield.
\end{abstract}

Keywords: Aromatic hydrocarbons, Chloromethylation, Catalytic system, Phase transfer catalysis.

\section{INTRODUCTION}

Chloromethylation of aromatic hydrocarbons was a very widely used reaction for well over half a century, both on a laboratory and industrial scale, and has been widely applied in synthesis of a variety of fine or special chemicals such as pharmaceuticals, agrochemicals, dyes, flavors and fragrances, monomers, additives, etc ${ }^{1-21}$. The reaction of aromatic hydrocarbons with hydrochloric acid and trioxane or paraformaldehyde as a formaldehyde precursor gave chloromethylated products without a catalyst, although the rate is slow and not enough for practical chemical process ${ }^{4-9}$. Lewis acids such as zinc chloride, stannic chloride, aluminum chloride, and boron trifluoride are well-known and excellent catalysts for the reaction ${ }^{10-15}$. Among these acids, zinc chloride is an effective catalyst in hydrochloric acid solution ${ }^{5,10-12}$, however, a large amount of catalyst against to substrate is required to obtain a reasonable product yield. These catalysts, in general, suffer from the inherent problems of tedious workup procedures, corrosiveness, high susceptibility to water, difficulty of catalyst recovery, environmental hazards, etc. Kishida et al. proposed rare earth metal triflates, particularly $\mathrm{Sc}(\mathrm{OTf})$, as the effective catalyst to synthesize chloromethylated hydrocarbons ${ }^{16,17}$, but the rare earth metal triflates are expensive and thus not suitable for industry. The use of ionic liquids ${ }^{18-20}$ and surfactant micelles ${ }^{21}$ as catalysts for the chloromethylation of aromatic hydrocarbons were also reported, these procedures, however, are invariably associated with certain limitations such as the expensive costs of ionic liquids, particularly [emim] $\mathrm{BF}_{4}$ (1-ethyl-3-methylimidazolium tetrafluoroborate), and the difficulty of catalyst recovery when use surfactant micelles, which impeded the use for practical chemical processes. So, it is important to develop environmentally conscious catalysts with high activity and reasonable prices for the chloromethylation of aromatic hydrocarbons.

Phase transfer catalysis (PTC) is a versatile synthetic technique of rate enhancement of a reaction between chemical species located in different phases (immiscible liquids or solid and liquid) by addition of a small quantity of an agent (phase transfer catalyst) that extracts one of the reactants, most commonly an anion, across the interface into the other phase so that reaction can proceed. By using a PTC process, one can achieve faster reactions, obtain higher conversions or yields, make fewer byproducts, eliminate the need for expensive or dangerous solvents which dissolve all the reactants in one phase, eliminate the need for expensive raw materials and/or minimize waste problems. At present, phase transfer catalysis has been applied in various organic synthesis ${ }^{22-28}$. The chloromethylation of aromatic hydrocarbons using strong acids has been proposed by some workers ${ }^{2,29-31}$, however, the systematic works on their catalytic properties, such as activity and have not been clarified yet. In this paper, we devise a novel catalytic system $\left(\mathrm{H}_{2} \mathrm{SO}_{4} / \mathrm{AcOH} / \mathrm{ZnCl}_{2} /\right.$ PEG-800) for the chloromethylation of aromatic hydrocarbons in aqueous media under PTC conditions (Scheme 1), we found that the catalytic system is active for the chloromethylation and that it is an environmentally conscious catalytic system.

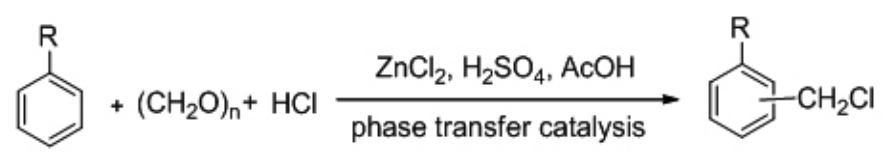

Scheme 1 Chloromethylation of aromatic hydrocarbons

\section{RESULTS AND DISCUSSION}

In a preliminary study, the chloromethylation of toluene was carried out in oil-water biphasic system in the presence and absence of PEG- 800 at $50^{\circ} \mathrm{C}$. As shown in Table 1, in the absence of PEG-800, the chloromethylation proceeded not well and the conversion was only $70 \%$ (Table 1 , entry 1 ) after $12 \mathrm{~h}$. Using PEG-800 (5 mmol) as phase transfer catalyst, under the same conditions, the conversion reached in a higher $80 \%$ (Table 1 , entry 2 ) in a shorter time $(8 \mathrm{~h})$. However, further addition the amount of PEG-800, under the same conditions, the conversion was not enhanced significantly (Table 1, entries 6 and 7). Besides PEG-800, we also tried to use another types of phase transfer catalysts such as PEG-200, PEG-400 and PEG-600 in the reaction. However, the conversions were $74 \%, 76 \%$, and $79 \%$ respectively (Table1, entries $3-5$ ). Thus, based on the results obtained, the best phase transfer catalyst is PEG- 800 .

Table 1.- PTC catalyzed chloromethylation of toluene with $\mathrm{ZnCl}_{2} /$ $\mathrm{AcOH} / 50 \% \mathrm{H}_{2} \mathrm{SO}_{4}$ in aqueous media ${ }^{\mathrm{a}}$

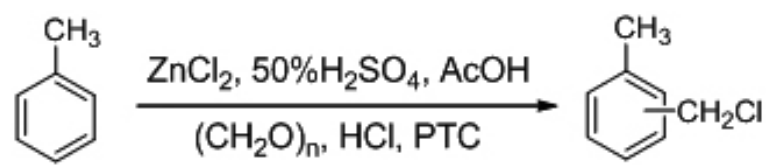

\begin{tabular}{|c|c|c|c|c|c|}
\hline Entry & $\begin{array}{c}\text { Phase } \\
\text { transfer } \\
\text { catalyst }\end{array}$ & $\begin{array}{c}\text { PTC } \\
(\mathrm{mmol})\end{array}$ & $\begin{array}{c}\text { Time } \\
(\mathrm{h})\end{array}$ & $\begin{array}{c}\text { Conversion } \\
(\%)^{\mathrm{b}}\end{array}$ & $\begin{array}{c}\text { P/O } \\
\text { Yield } \\
(\%)^{\mathrm{c}, \mathrm{d}}\end{array}$ \\
\hline 1 & - & - & 12 & 70 & $51 / 19$ \\
\hline 2 & PEG-800 & 5 & 8 & 80 & $72 / 8$ \\
\hline 3 & PEG-600 & 5 & 8 & 79 & $69 / 10$ \\
\hline 4 & PEG-400 & 5 & 8 & 76 & $64 / 12$ \\
\hline 5 & PEG-200 & 5 & 8 & 74 & $59 / 15$ \\
\hline 6 & PEG-800 & 5.5 & 8 & 80 & $72 / 8$ \\
\hline 7 & PEG-800 & 6 & 8 & 80 & $72 / 8$ \\
\hline
\end{tabular}

a Reaction conditions: toluene $(0.1 \mathrm{~mol})$, paraformaldehyde $(0.105 \mathrm{~mol})$, $50 \% \mathrm{H}_{2} \mathrm{SO}_{4}(60 \mathrm{~mL}), \mathrm{AcOH}(30 \mathrm{~mL}), \mathrm{ZnCl}_{2}(0.1 \mathrm{~mol})$, anhydrous hydrogen chloride gas $(10 \mathrm{~mL} / \mathrm{min}), 50^{\circ} \mathrm{C}$.

bIsolated conversion.

${ }^{\mathrm{P}} \mathrm{P}$ is 1-(chloromethyl)-4-methylbenzene; $\mathrm{O}$ is 1-(chloromethyl)-2methylbenzene.

dP/O for each sample was determined by HPLC.

Figure 1 shows the influences of the concentration of sulfuric acid on the chloromethylation at $50^{\circ} \mathrm{C}$. In the absence of sulfuric acid (i.e. the concentration of sulfuric acid is zero), the chloromethylation reaction proceeded very slowly, 
only $7 \%$ conversion was obtained after $8 \mathrm{~h}$, and the increase in the concentration of sulfuric acid enhanced the catalysis. The conversion reached maximum at the $50 \%$ sulfuric acid, however, it decreased with further increase of the concentration of sulfuric acid. Figure 2 shows the influences of the volume ratio of $\mathrm{AcOH}$ and $50 \% \mathrm{H}_{2} \mathrm{SO}_{4}$ on the reaction. In the absence of acetic acid, the chloromethylation reaction proceeded not well, only $56 \%$ conversion was obtained after $8 \mathrm{~h}$, and the increase in the amount of acetic acid (i.e. the volume ratio increased) enhanced the catalysis, the conversion reached maximum at 0.5 of the ratio. However, the conversion decreased slowly with further increase in the amount of acetic acid. One possibility for the role of acetic acid may be due to the enhancement of solubility to prompt the contact of paraformaldehyde with toluene by the solvation, however, further studies are necessary for the clarification of the mechanism.

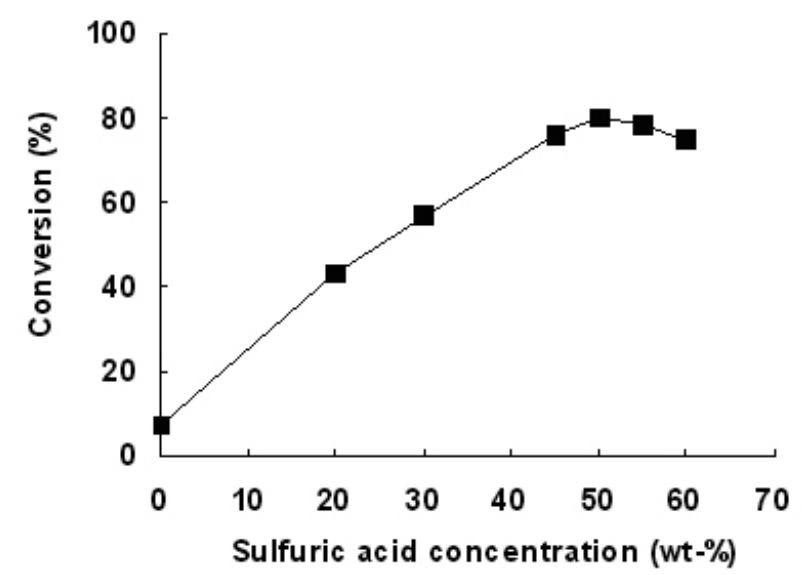

Figure 1 Influences of concentration of sulfuric acid on the chloromethylation. Reaction conditions: toluene $(0.1 \mathrm{~mol})$, paraformaldehyde (0.105 mol), $\mathrm{H}_{2} \mathrm{SO}_{4}(60 \mathrm{~mL}), \mathrm{AcOH}(30 \mathrm{~mL}), \mathrm{ZnCl}_{2}(0.1 \mathrm{~mol}), \mathrm{PEG}-800$ (5 $\mathrm{mmol})$, anhydrous hydrogen chloride gas $(10 \mathrm{~mL} / \mathrm{min}), 50{ }^{\circ} \mathrm{C}, 8 \mathrm{~h}$.

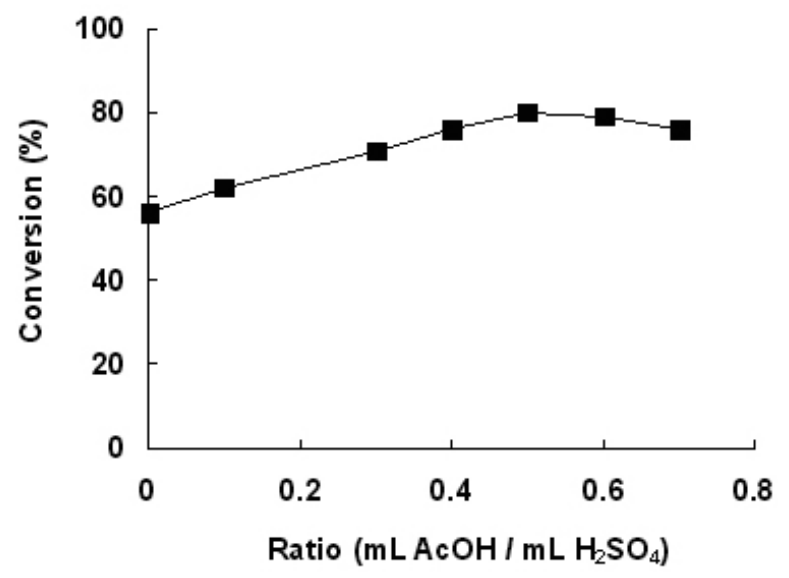

Figure 2 Influences of amount of acetic acid on the chloromethylation. Reaction conditions: toluene $(0.1 \mathrm{~mol})$, paraformaldehyde $(0.105 \mathrm{~mol}), 50 \%$ $\mathrm{H}_{2} \mathrm{SO}_{4}(60 \mathrm{~mL}), \mathrm{ZnCl}_{2}(0.1 \mathrm{~mol})$, PEG-800 $(5 \mathrm{mmol})$, anhydrous hydrogen chloride gas $(10 \mathrm{~mL} / \mathrm{min}), 50^{\circ} \mathrm{C}, 8 \mathrm{~h}$.

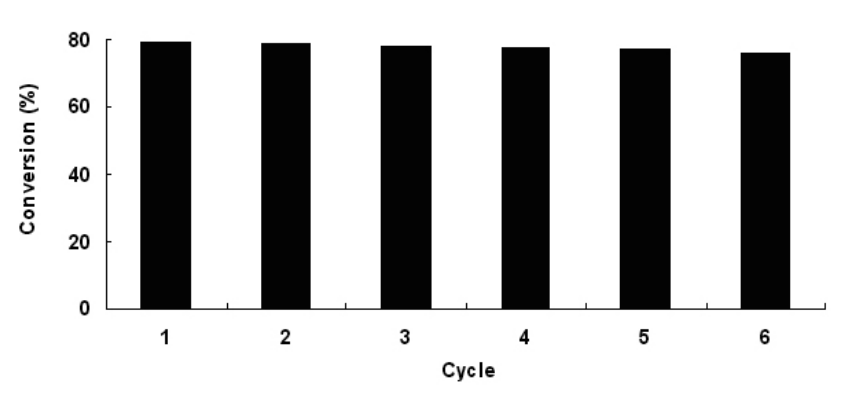

In addition, the catalytic system could be typically recovered and reused for subsequent reactions (Figure 3). The recycling process involved the product layer (upper layer) was extracted with methylene chloride and the catalytic system layer (under layer) was concentrated to remove water produced in the reaction through water knockout drum. Fresh subtrates were then recharged to the recovered catalytic system and the mixture was heated to react once again, and only $5.0 \%$ loss of weight was observed after 6 times recycling.

Figure 3 Repeating reactions using recovered catalytic system. Reaction conditions: toluene $(0.1 \mathrm{~mol})$, paraformaldehyde $(0.105 \mathrm{~mol})$, recovered catalytic system $\left(\mathrm{ZnCl}_{2} / \mathrm{AcOH} / 50 \% \mathrm{H}_{2} \mathrm{SO}_{4} / \mathrm{PEG}-800\right)$, anhydrous hydrogen chloride gas $(10 \mathrm{~mL} / \mathrm{min}), 50{ }^{\circ} \mathrm{C}, 8 \mathrm{~h}$.

With these results in hand, we subjected other aromatic hydrocarbons to the chloromethylation reactions, and the results are listed in Table 2. Various aromatic hydrocarbons were efficiently converted to the corresponding chloromethylated product in good to excellent isolated conversion using the catalytic system (Table 2, entries 1-11). The aromatic hydrocarbons such as toluene, ethylbenzene, xylene, cumene, 4-methylphenoxide, tertbutylbenzene and tetrahydronaphthalene gave products in higher conversions under milder reaction conditions (Table 2, entries 2-10) than that of benzene (Table 2, entry 1) and biphenyl (Table 2, entry 11), which was attributed to the electrondonating effect of alkyl group, that may be explains why they showed more active for the reactions. While in the case of chlorobenzene and benzoic acid for the chloromethylation, we did not obtain satisfactory results, even under more drastic reaction conditions, chloromethylation of benzoic acid gave no corresponding product (Table 2 , entry 12 ) and the conversion of the chloromethylation of chlorobenzene was merely $3 \%$ (Table 2 , entry 13 ). 
Table 2 Chloromethylation of aromatic hydrocarbons catalyzed by $\mathrm{ZnCl}_{2} / \mathrm{AcOH} / \mathrm{H}_{2} \mathrm{SO}_{4} / \mathrm{PEG}-800$ in aqueous media ${ }^{\mathrm{a}}$

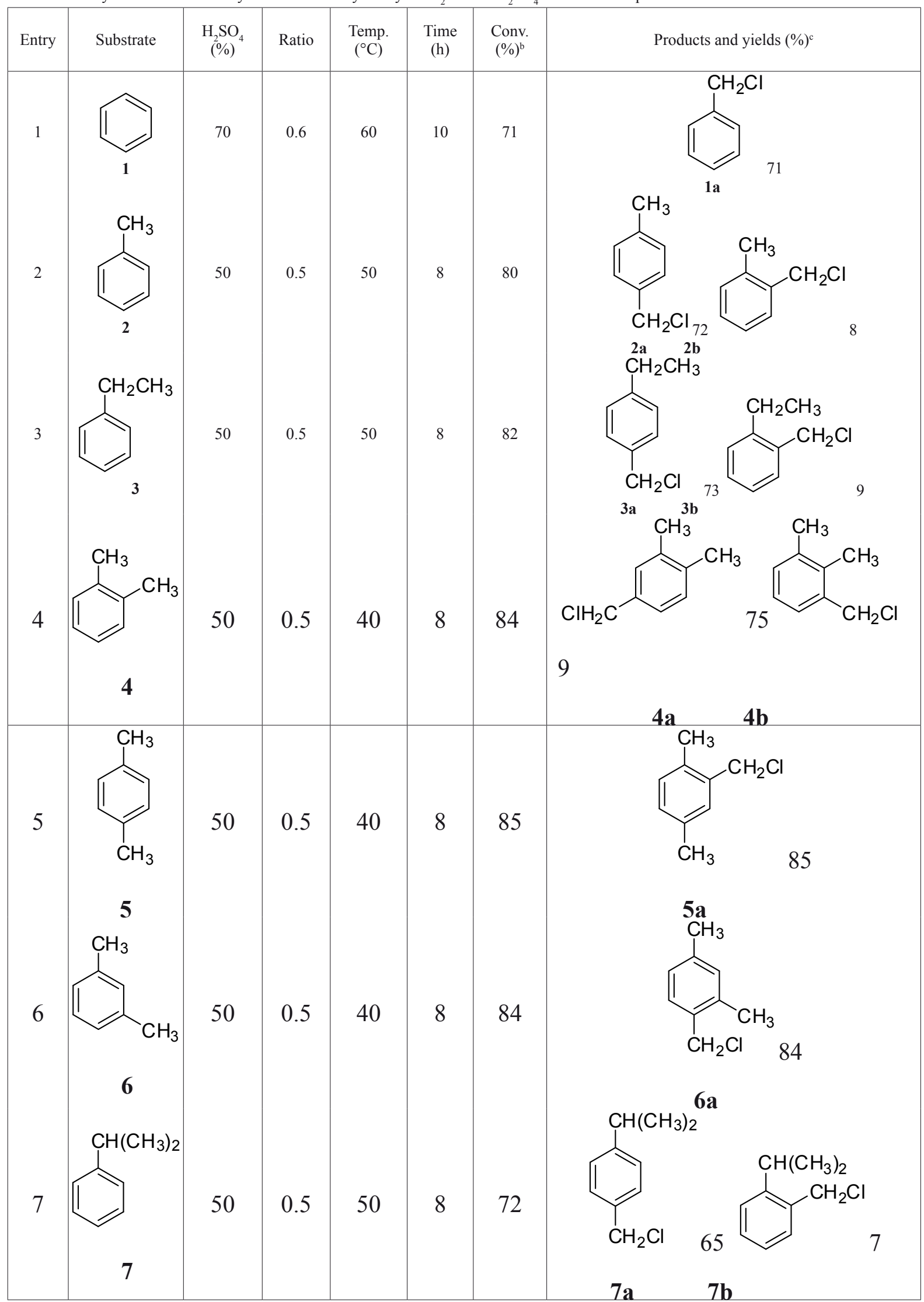




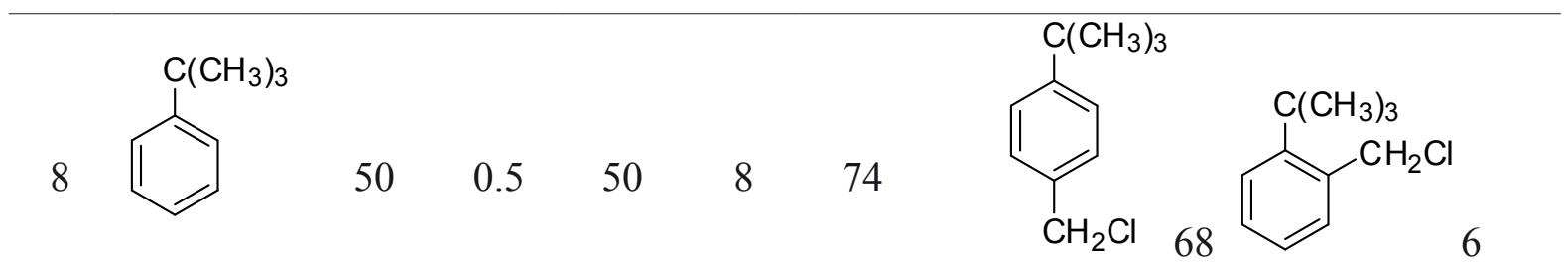

8<smiles>Cc1ccc(O)c(CCl)c1</smiles>

82

10<smiles>Cc1ccc(O)cc1</smiles>

50

$0.5 \quad 50 \quad 8$

82

50

$\begin{array}{lll}0.4 & 50 \quad 8\end{array}$

83<smiles>ClCc1ccc2c(c1)CC[C]([Te])C2</smiles>

10

$\begin{array}{llll}75 & 1.0 & 60 & 10\end{array}$

68<smiles>ClCc1ccc(-c2ccccc2)cc1</smiles>

$0 a$

$10 b$

11<smiles>c1ccc(-c2ccccc2)cc1</smiles>

11

12<smiles>O=C(O)c1ccccc1</smiles>

90

$\begin{array}{lll}0.8 & 85 \quad 16\end{array}$

0

$11 \mathrm{a} \quad 11 \mathrm{~b}$

12

13<smiles>Clc1ccccc1</smiles>

90

0.8

85

16

3<smiles>ClCc1ccc(Cl)cc1</smiles>

13

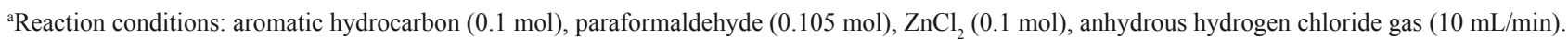
${ }^{\mathrm{b}}$ Isolated conversion.

'Yields for each sample were determined by HPLC.

${ }^{\mathrm{d}}$ no product was detected. 
The excellent catalytic abilities of the catalytic system suggest the chloromethylation reaction among aromatic hydrocarbons, formaldehyde, zinc chloride, acetic acid, sulfuric acid and PEG-800 has a particular mechanism. Scheme 2 shows a plausible mechanistic pathway for the chloromethylation of aromatic hydrocarbons. Before the chloromethylation, there exists an obvious oil-water biphasic system, and the under layer (water phase) consists of zinc chloride, acetic acid, sulfuric acid and formaldehyde, the upper layer (oil phase) is the substrate (aromatic hydrocarbon), and PEG-800 exists between the two phases. During the process of chloromethylation, the oil-water biphasic system disappeares and a homogeneous reaction medium is formed by phase transfer catalysis. It is considered that the activation of formaldehyde is a first step for the enhancement of the chloromethylation ${ }^{18,21}$. Firstly, depolymerization of paraformaldehyde by acid catalysis of hydrochloric acid yields formaldehyde which reacts with proton $\left(\mathrm{H}^{+}\right)$to yield hydroxymethyl cation $\left({ }^{+} \mathrm{CH}_{2} \mathrm{OH}\right)$ and the electrophilic substitution reaction mainly occurs by subsequent attack of the ${ }^{+} \mathrm{CH}_{2} \mathrm{OH}$ on benzene ring of aromatic hydrocarbons to give aromatic carbinol; then the resulting alcohol under the action of acid gives a benzyl carbonium ion and water very rapidly; finally, the benzyl carbonium ion reacts with anions $\mathrm{Cl}^{-}$ to yield the desired products. Afer the completion of the reaction, a complete phase-separation is formed again after being cooled to room temperature, the upper layer of the product, was removed by extraction with methylene chloride and the catalytic system, containing zinc chloride, acetic acid, sulfuric acid and PEG-800, was concentrated to remove water produced in the reaction through water knockout drum and then recycle.
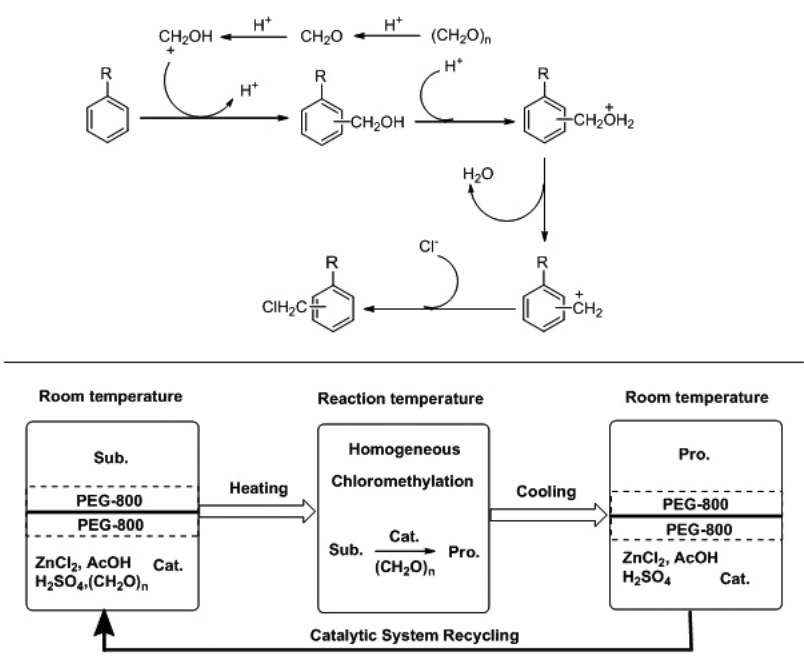

Scheme 2. Plausible mechanism of chloromethylation of aromatic hydrocarbons

\section{CONCLUSIONS}

In summary, the catalytic system $\left(\mathrm{ZnCl}_{2} / \mathrm{AcOH} / \mathrm{H}_{2} \mathrm{SO}_{4} / \mathrm{PEG}-800\right)$ has been proven to be an effective promoter for the chloromethylation of aromatic hydrocarbons. The chloromethyl acid complex consisting of a certain concentration of sulphuric acid and acetic acid in a peculiar volume ratio for the chloromethylation is the first glittery point in our paper, which can be use efficiently for the chloromethylation of various aromatic hydrocarbons by changing the concentration of sulfuric acid and the volume ratio of sulfuric acid and acetic acid. This procedure not only enhanced the yield, but also the selectivity for para-chloromethylated product could almost be improved by $5 \sim 15 \%$ contrast to other procedures catalyzed by lewis acids, ionic liquids, rare-earth metal triflates, etc ${ }^{4-21}$, whose selectivity for para-isomer were usually $70 \sim 82 \%$. Another glittery point was that we have developed an inexpensive, old but new, efficient, and convenient chloromethylation procedure catalyzed by $\mathrm{ZnCl}_{2} / \mathrm{AcOH} / \mathrm{H}_{2} \mathrm{SO}_{4} / \mathrm{PEG}-800$ in aqueous media under PTC conditions, the present method has many obvious advantages compared to previous methods, such as easy product isolation, simple methodology, the excellent yield, generality, and the excellent recyclability of the catalytic system, etc, though it is not satisfied for the chloromethylation of desactivating aromatic hydrocarbons such as benzoic acid and chlorobenzene.

Judging from the conditions employed, this chloromethylation method showed has great prospects in industrial applications. Further aspects of the catalysis, the application to organic synthesis, and practical chemical processes are under investigation.

\section{EXPERIMENTAL}

\section{Apparatus and reagents}

All chemicals were obtained commercially and used without further purification. The target products were characterized by Elemental analysis, ${ }^{1} \mathrm{H}$ NMR, or compared with their authentic samples. ${ }^{1} \mathrm{H}$ NMR spectra were recorded on a Bruker $400 \mathrm{MHz}$ spectrometer using $\mathrm{CDCl}_{3}$ as the solvent with tetramethylsilane (TMS) as an internal standard. High performance liquid chromatography (HPLC) experiments were performed on a liquid chromatograph (Dionex Softron GmbH, America), consisting of a pump (P680) and ultraviolet-visible light detector (UVD) system (170U). The experiments were performed on Diacovery C18 column, $\varnothing 4.6 \times 150 \mathrm{~mm}$. Elemental analysis were performed on a Vario EL III instrument (Elmentar Anlalysensy Teme GmbH, Germany).

Typical procedure of chloromethylation using toluene as an example

A $250 \mathrm{~mL}$ three-necked flask was loaded with toluene $(9.2 \mathrm{~g}, 0.1 \mathrm{~mol})$, paraformaldehyde ( $3.15 \mathrm{~g}, 0.105 \mathrm{~mol}), \mathrm{ZnCl}_{2}(13.6 \mathrm{~g}, 0.1 \mathrm{~mol}), 50 \% \mathrm{H}_{2} \mathrm{SO}_{4}(60$ $\mathrm{mL}), \mathrm{AcOH}(30 \mathrm{~mL})$ and PEG-800 (4 g, $5 \mathrm{mmol})$. Hydrogen chloride gas was bubbled into the flask at the flow rate of $10 \mathrm{~mL} / \mathrm{min}$. The reaction mixture was stirred at $50^{\circ} \mathrm{C}$ for $8 \mathrm{~h}$, the reaction progress was monitored by HPLC. After the reaction, the reaction mixture was cooled to room temperature and extracted with methylene chloride $(3 \times 10 \mathrm{~mL})$. The organic phases were combined and rinsed with $50 \% \mathrm{NaHCO}_{3}$ solution $(3 \times 10 \mathrm{~mL})$ and water $(2 \times 10 \mathrm{~mL})$, then dried with sodium sulfate, filtered, and evaporated to dryness in vacuo, and the organic residue was resolved in methylene chloride and analyzed by HPLC. Each product was separated by silica-gel column chromatography, then the solvent was removed under vacuum to give the desired product. The next run was performed under identical reaction conditions.

4-(chloromethyl)-1,2-dimethylbenzene (4a): ${ }^{1} \mathrm{H}$ NMR $\left(\mathrm{CDCl}_{3}\right)$ : $\delta$ 7.04$7.16(\mathrm{~d}, 3 \mathrm{H}, \mathrm{ArH}), 4.56\left(\mathrm{~s}, 2 \mathrm{H}, \mathrm{CH}_{2} \mathrm{Cl}\right), 2.33$ (s, 6H, CH $)$. Anal. Calc. for $\mathrm{C}_{9} \mathrm{H}_{11} \mathrm{Cl}$ : C, 69.90; H, 7.17; $\mathrm{Cl}, 22.93 \%$. Found: $\mathrm{C}, 69.86 ; \mathrm{H}, 7.16 ; \mathrm{Cl}, 22.92 \%$.

1-(chloromethyl)-2,3-dimethylbenzene (4b): ${ }^{1} \mathrm{H}$ NMR $\left(\mathrm{CDCl}_{3}\right): \delta 7.07-$ $7.24(\mathrm{~m}, 3 \mathrm{H}, \mathrm{ArH}), 4.57\left(\mathrm{~s}, 2 \mathrm{H}, \mathrm{CH}_{2} \mathrm{Cl}\right), 2.35\left(\mathrm{~s}, 3 \mathrm{H}, \mathrm{CH}_{3}\right), 2.21\left(\mathrm{~s}, 3 \mathrm{H}, \mathrm{CH}_{3}\right)$ Anal. Calc. for $\mathrm{C}_{9} \mathrm{H}_{11} \mathrm{Cl}: \mathrm{C}, 69.90 ; \mathrm{H}, 7.17 ; \mathrm{Cl}, 22.93 \%$. Found: $\mathrm{C}, 69.89 ; \mathrm{H}$, 7.17; $\mathrm{Cl}, 22.91 \%$.

2-(chloromethyl)-1,4-dimethylbenzene (5a): ${ }^{1} \mathrm{H}$ NMR $\left(\mathrm{CDCl}_{3}\right)$ : $\delta$ 7.087.19 (d, 3H, ArH), 4.59 (s, 2H, CH Cl), $2.37\left(\mathrm{~s}, 3 \mathrm{H}, \mathrm{CH}_{3}\right), 2.32\left(\mathrm{~s}, 3 \mathrm{H}, \mathrm{CH}_{3}\right)$. Anal. Calc. for $\mathrm{C}_{9} \mathrm{H}_{11} \mathrm{Cl}$ : C, 69.90; $\mathrm{H}, 7.17 ; \mathrm{Cl}, 22.93 \%$. Found: $\mathrm{C}, 69.88 ; \mathrm{H}$, 7.18; $\mathrm{Cl}, 22.89 \%$

1-(chloromethyl)-2,4-dimethylbenzene (6a): ${ }^{1} \mathrm{H}$ NMR $\left(\mathrm{CDCl}_{3}\right)$ : $\delta$ 7.03$7.18(\mathrm{~m}, 3 \mathrm{H}, \mathrm{ArH}), 4.55\left(\mathrm{~s}, 2 \mathrm{H}, \mathrm{CH}_{2} \mathrm{Cl}\right), 2.36\left(\mathrm{~s}, 3 \mathrm{H}, \mathrm{CH}_{3}\right), 2.31\left(\mathrm{~s}, 3 \mathrm{H}, \mathrm{CH}_{3}\right)$. Anal. Calc. for $\mathrm{C}_{9} \mathrm{H}_{11} \mathrm{Cl}$ : C, 69.90; H, 7.17; Cl, 22.93\%. Found: C, 69.87; $\mathrm{H}$, 7.19; $\mathrm{Cl}, 22.91 \%$.

1-(chloromethyl)-4-isopropylbenzene (7a): ${ }^{1} \mathrm{H}$ NMR $\left(\mathrm{CDCl}_{3}\right): \delta 7.34(\mathrm{~m}$, $2 \mathrm{H}, \mathrm{ArH}), 7.18(\mathrm{~m}, 2 \mathrm{H}, \mathrm{ArH}), 4.48\left(\mathrm{~s}, 2 \mathrm{H}, \mathrm{CH}_{2} \mathrm{Cl}\right), 2.84(\mathrm{~m}, \mathrm{H}, \mathrm{CH}), 1.54(\mathrm{~d}$, $6 \mathrm{H}, \mathrm{CH}_{3}$ ). Anal. Calc. for $\mathrm{C}_{10} \mathrm{H}_{13} \mathrm{Cl}: \mathrm{C}, 71.21 ; \mathrm{H}, 7.77 ; \mathrm{Cl}, 21.02 \%$. Found: $\mathrm{C}$, $71.17 ; \mathrm{H}, 7.76 ; \mathrm{Cl}, 21.01 \%$.

1-(chloromethyl)-2-isopropylbenzene (7b): ${ }^{1} \mathrm{H}$ NMR $\left(\mathrm{CDCl}_{3}\right): \delta$ 7.14-7.29 (m, 4H, $\mathrm{ArH}), 4.51\left(\mathrm{~s}, 2 \mathrm{H}, \mathrm{CH}_{2} \mathrm{Cl}\right), 2.83(\mathrm{~m}, \mathrm{H}, \mathrm{CH}), 1.56\left(\mathrm{~d}, 6 \mathrm{H}, \mathrm{CH}_{3}\right)$. Anal. Calc. for $\mathrm{C}_{10} \mathrm{H}_{13} \mathrm{Cl}$ : C, $71.21 ; \mathrm{H}, 7.77 ; \mathrm{Cl}, 21.02 \%$. Found: $\mathrm{C}, 71.19 ; \mathrm{H}, 7.78$; $\mathrm{Cl}, 21.00 \%$.

2-(chloromethyl)-4-methylphenol (9a): ${ }^{1} \mathrm{H}$ NMR $\left(\mathrm{CDCl}_{3}\right): \delta 6.98-7.17(\mathrm{~m}$, $3 \mathrm{H}, \mathrm{ArH}), 5.39(\mathrm{~s}, 1 \mathrm{H}, \mathrm{OH}), 4.57\left(\mathrm{~s}, 2 \mathrm{H}, \mathrm{CH}_{2} \mathrm{Cl}\right), 2.84(\mathrm{~m}, \mathrm{H}, \mathrm{CH})$. Anal. Calc. for $\mathrm{C}_{8} \mathrm{H}_{9} \mathrm{ClO}$ : $\mathrm{C}, 61.35 ; \mathrm{H}, 5.79 ; \mathrm{Cl}, 22.64 ; \mathrm{O}, 10.22 \%$. Found: $\mathrm{C}, 61.31 ; \mathrm{H}$, $5.79 ; \mathrm{Cl}, 22.63 ; \mathrm{O}, 10.19 \%$.

6-(chloromethyl)-1,2,3,4-tetrahydronaphthalene (10a): ${ }^{1} \mathrm{H} \mathrm{NMR}\left(\mathrm{CDCl}_{3}\right)$ : $\delta$ 7.03-7.11 (m, 3H, ArH), $4.56\left(\mathrm{~s}, 2 \mathrm{H}, \mathrm{CH}_{2} \mathrm{Cl}\right), 2.81\left(\mathrm{~s}, 2 \mathrm{H}, \mathrm{CH}_{2}\right), 1.53(\mathrm{~s}, 2 \mathrm{H}$, $\mathrm{CH}_{2}$ ). Anal. Calc. for $\mathrm{C}_{11} \mathrm{H}_{13} \mathrm{Cl}: \mathrm{C}, 73.12 ; \mathrm{H}, 7.25 ; \mathrm{Cl}, 19.62 \%$. Found: $\mathrm{C}, 73.08$; $\mathrm{H}, 7.26 ; \mathrm{Cl}, 19.59 \%$.

5-(chloromethyl)-1,2,3,4-tetrahydronaphthalene (10b): ${ }^{1} \mathrm{H} \mathrm{NMR}\left(\mathrm{CDCl}_{3}\right)$ : $\delta$ 7.00-7.09 (m, 3H, ArH), $4.54\left(\mathrm{~s}, 2 \mathrm{H}, \mathrm{CH}_{2} \mathrm{Cl}\right), 2.83\left(\mathrm{~s}, 2 \mathrm{H}, \mathrm{CH}_{2}\right), 1.55(\mathrm{~s}, 2 \mathrm{H}$, $\mathrm{CH}_{2}$ ). Anal. Calc. for $\mathrm{C}_{11} \mathrm{H}_{13} \mathrm{Cl}: \mathrm{C}, 73.12 ; \mathrm{H}, 7.25 ; \mathrm{Cl}, 19.62 \%$. Found: C, 73.07; $\mathrm{H}, 7.24 ; \mathrm{Cl}, 19.61 \%$.

4-(chloromethyl)biphenyl (11a): ${ }^{1} \mathrm{H}$ NMR $\left(\mathrm{CDCl}_{3}\right): \delta$ 7.39-7.57 (m, 9H, $\mathrm{ArH}), 4.63\left(\mathrm{~s}, 2 \mathrm{H}, \mathrm{CH}_{2} \mathrm{Cl}\right.$ ). Anal. Calc. for $\mathrm{C}_{13} \mathrm{H}_{11} \mathrm{Cl}: \mathrm{C}, 77.04 ; \mathrm{H}, 5.47 ; \mathrm{Cl}$, $17.49 \%$. Found: C, $77.01 ; \mathrm{H}, 5.46 ; \mathrm{Cl}, 17.47 \%$.

4,4'-bis(chloromethyl)biphenyl (11b): ${ }^{1} \mathrm{H}$ NMR $\left(\mathrm{CDCl}_{3}\right): \delta 7.46(\mathrm{~m}, 4 \mathrm{H}$, $\mathrm{ArH}), 7.58(\mathrm{~m}, 4 \mathrm{H}, \mathrm{ArH}), 4.64\left(\mathrm{~s}, 2 \mathrm{H}, \mathrm{CH}_{2} \mathrm{Cl}\right)$. Anal. Calc. for $\mathrm{C}_{14} \mathrm{H}_{12} \mathrm{Cl}_{2}: \mathrm{C}$, 66.95; H, 4.82; Cl, 28.23\%. Found: C, 66.89; H, 4.83; Cl, 28.24\%.

1-chloro-4-(chloromethyl)benzene (13a): ' $\mathrm{H}$ NMR $\left(\mathrm{CDCl}_{3}\right): \delta 7.41(\mathrm{~m}$, 
$2 \mathrm{H}, \mathrm{ArH}), 7.23(\mathrm{~m}, 2 \mathrm{H}, \mathrm{ArH}), 4.59$ (s, $\left.2 \mathrm{H}, \mathrm{CH}_{2} \mathrm{Cl}\right)$. Anal. Calc. for $\mathrm{C}_{7} \mathrm{H}_{6} \mathrm{Cl}_{2}: \mathrm{C}$, $52.21 ; \mathrm{H}, 3.76 ; \mathrm{Cl}, 44.03 \%$. Found: $\mathrm{C}, 52.18 ; \mathrm{H}, 3.75 ; \mathrm{Cl}, 44.01 \%$.

\section{ACKNOWLEDGEMENTS}

We thank the Ministry of Education of the Republic of China and Natural Science Foundation of Jiangsu Province for support of this research.

\section{REFERENCES}

1. H. H. Szmant, J. Dudek, J. Am. Chem. Soc. 71, 3763-3765, (1949)

2. I. Hirao, T. Matsuura, K. Ota, Yuki Gosei Kagaku Kyoukaishi 23, 248, (1965)

3. G. A. Olah, M. R. Bruce, J. Am. Chem. Soc. 101, 4765, (1979)

4. C. D. Shacklett, H. A. Smith, J. Am. Chem. Soc. 73, 766, (1951)

5. N. Rabjohn, J. Am. Chem. Soc. 76, 5479, (1954)

6. W. G. J. De Pierri, H. W. Eahart, U.S. Patent 2964573, 1960

7. B. Kanakalashmi, K. P. Mathai, S. Sethna, J. Indian Chem. Soc. 43, 469, (1966)

8. M. Selva, F. Trotta, P. Tundo, Synthesis 1003-1004, (1991)

9. M. Gerisch, J. R. Krumper, R. G. Bergman, T. D. Tilley, Organometallics 22, 47-58, (2003)

10. R.C. Fuson, C. H. McKeever, Organic Reactions, vol. 1, John Wiley, New York, 1943; pp. 63-90

11. G. A. Olah, Friedel Crafts and Related Reactions, vol. 2, Part 2, John Wiley, New York, 1964; pp. 659-784

12. M. Wakae, K. Konishi, Yuki Gosei Kagaku Kyoukaishi 14, 615, (1956)
13. R. Granger, H. Orzalesi, A. Muratelle, Compt. Rend. 249, 2337, (1959)

14 A. A. Vansheidt, E. P. Melnikova, A. T. Yu. Zh. Prikl. Khim. 34, 705, (1961)

15. K. Yamauchi, T. Kishida, Y. Sugi, Y. Kubota, J.P. Patent 2004002333, 2004

16. T. Kishida, T. Yamauchi, Y. Kubota, Green Chem. 6, 57, (2004)

17. T. Kishida, T. Yamauchi, K. Komura, Y. Kubota, Y. Sugi, J. Mol. Catal. A: Chem. 46, 268, (2006)

18. K. Qiao, Y.Q. Deng, Acta Chim. Sin. 61, 133-136, (2003)

19. Y. Wang, Z. C. Shang, T. X. Wu, Synth. Commun. 36, 3053-3059, (2006)

20. Y. X. Fang, Y. Q. Deng, Q. G. Ren, Chin. J. Chem. Eng. 16, 357-360, (2008)

21. Q. F. Liu, M. Lu, Y. Q. Li, J. Mol. Catal. A: Chem. 277, 113-118, (2007)

22. C. M. Stark, C. L. Liotta, Phase Transfer Catalysis Principles and Techniques, Academic Press, New York, 1978

23. S. L. Regen, A. Nigam, J. J. Besse, Tetrahedron Lett. 19, 2757, (1978)

24. J. O. Metzger, Angew. Chem. Int. Ed. 37, 2975-2978, (1998)

25. M. Mieczyslaw, Pure Appl. Chem. 72, 1399-1403, (2000)

26. E. Kaczmarczyk, E. Janus, E. Milchert, J. Mol. Catal. A: Chem. 244, 173, (2006)

27. A. R. Jones, Quaternary Ammonium Salts: Their Use in Phase Transfer Catalysis (Best Synthetic Methods), Elsevier, 2001

28. P. Vanysek, R. L. Basaez, J. Chil. Chem. Soc. 53, 1455-1463, (2008)

29. R. Motoyama, T. Fujimoto, T. Kakehi, J.P. Patent 38002863, 1963

30. P. T. Anastas, T. C. Williamson, Green Chemistry: Frontiers in Benign Chemical Synthesis and Processes, Oxford University Press, Oxford, 1998

31. E. P. Serjeant, B. E. Dempsey, Ionization Constants of Organic Acids in Solution, IUPAC Chemical Data Series No. 23, Pergamon Press, Oxford, 1979. 